\title{
Local Wisdom in the Ecolexicon Used in the New Version of Karonese Traditional Game "Cengkah- Cengkah"
}

\author{
Bahagia Tarigan and Rudy Sofyan \\ Faculty of Cultural Sciences, University of Sumatera Utara \\ Medan, Indonesia \\ bahagiatarigan@yahoo.com \\ rudy@usu.ac.id
}

\begin{abstract}
Cengkah-cengkahused to be one of the traditional games in Karonese society, particularly those living in Salapian SubDistrict, North Sumatra, Indonesia. However, it is no longer played by today's Karonese young generation as they are more attracted to today's more sophisticated games. As a matter of fact, a traditional game, such as cengkah-cengkah, provides a lot of advantages not only to children's physical development but also to language maintenance because the tool and the arena used in this game are taken from the surrounding ecology. Therefore, the surrounding ecology-related lexicon in Karonese language can be well-maintained as long as the game is played. This research employed an ecolinguistic and sociolinguistic approaches to revitalize "cengkah-cengkah" game in order that the ecolexicon associated with the game can be maintained. This article is a part of the research which is specifically aimed at finding out the local wisdom in the ecolexicon used in the Karonese traditional game "cengkah-cengkah". The research location was in two villages in Salapian Sub-District of North Sumatra Province: Lau Kambing and Turangi. The data were ecolexicon used in the new version of "cengkah-cengkah" game collected through observation and interview involving 10 informants who permanently domiciled in the two villages. The data were analyzed using the interactive model proposed by Miles, Huberman and Saldana (2014, p. 31-33). Based on the data analysis, it was found that: (i) the ecolexicon used in the new version of "cengkah-cengkah" represented the typical characteristics of Karonese native people in Lau Kambing and Turangi; and (ii) the ecolexicon used in the new version of "cengkah-cengkah" symbolized the hierarchy of merga in Karonese ethnic group living in Lau Kambing and Turangi.
\end{abstract}

Keywords—cengkah-cengkah; ecolexicon; Karonese traditional game; local wisdom

\section{INTRODUCTION}

"Cengkah-cengkah" is a Karonese traditional game used to be played by children at school or at home. In most of the parts in Indonesia, cengkah-cengkahis called engklek (hopscotch). This game, in fact, contributes a lot to the children's gross motor development (Rochmani 2016), i.e. hopping with one of the legs as the foothold while being careful from any possible injuries (Hasan 2009, p. 140). However, it is no longer played by today's Karonese generation in Salapian Sub-District, North Sumatra, Indonesia, particularly in Lau Kambing and Turangi Villages. According to Tarigan (2017), in Salapian Sub-district, Karonese people within the age group of 10 to 15 years old do not recognize this game, meaning that this game has not been played since 15 years ago. Most of the children prefer to play more sophisticated games utilizing the advance of current technology. The loss of cengkah-cengkah game certainly affects the lexicons associated with it. One of the types of lexicons used in this game is ecology-related lexicon, known as ecolexicon.The term "ecolexicon" refers to a multimodal and multilingual terminological knowledge base on the environment(Faber, León-Araúzand Reimerink 2014, 2016)

Adopted from the term physical environment proposed by Sapir (2001, p. 14), ecolexicon is composed of lexicons related to geographical characters such as the topography of the country (whether coast, valley, plain, plateau, or mountain), climate, and amount of rainfall, fauna, flora, and mineral resources of the region. Ecolexicon in a certain language, particularly a local language, is sensitive to die because it is often replaced by a more powerful language, either a national or international language. Tarigan (2017), who focused his study on flora-related ecolexicon, found that $59.34 \%$ of Karonese wild flora lexicon and $38.4 \%$ of Karonese cultivated flora lexicon were replaced by Indonesian lexicon. One of the factors leading to such death words is the children's earlier acquisition of ecolexicon from school introducing them in bahasa Indonesia.

Therefore, a serious effort to revitalize cengkah-cengkah game in the Karonese society living in Lau Kambing and Turangi is urgently needed. Nevertheless, in addition to the game revitalization, cengkah-cengkah also needs to be renewed or modified by empowering more available local resources through which the Karonese customs and tradition in Lau Kambing and Turangi can be reflected. The modification of cengkah-cengkah in this research is done by inserting more ecolexicon into the game either as the tool or the rule.The purpose of inserting more ecolexicon in the renewed cengkah-cengkah game is to maintain the local ecolexicon and to generate the local wisdom of the existence of such ecology in the local environment. Maintaining traditional game-related ecolexicon showsone of the efforts of language maintenance, the continuous use of local language (Wardaugh and 
Fuller 2015, p. 85). This is in line with Holmes (2013, p. 66) who identifies several factors affecting the efforts of language maintenance: (i) the status of the language as indicated by attitudes towards it; (ii) the size ofthe group who uses the language and their distribution; and (iii) the extent to which the language enjoys institutional support. Thus, this "new version" of cengkahcengkah introduced in this article can be regarded as an effort to maintain Karonese language spoken in Lau Kambing and Turangi.

Previous studies on traditional games in Indonesia were conducted mainly from sociolinguistic, ethnolinguistic, anthropolinguistic, pragmatic and educational perspectives but very few were conducted from ecolinguistic perspective. Jaenudin (2013), for example, studied the Sundanese words for tools made from bamboos used in Sundanese traditional games from ecolinguistic perspectives. However, he did not specify his study on a certain traditional game, and did not renew or modify it. Another study done by Lubis (2014) focused on the language shift in the Mandailing traditional games. Meanwhile, this study aims at revitalizing and renewing the Karonese traditional game cengkah-cengkah by inserting more ecolexicon and finding out the local wisdom contained in such ecolexicon.

This is a qualitative research for its purpose of exploring a problem and developing a detailed understanding of a central phenomenon (Creswell 2012, p. 16), i.e. the new version of Karonese traditional game "cengkah-cengkah". The data were the ecolexicon associated with the new version of Karonese traditional game "cengkah-cengkah". The research location was in two villages at Salapian Sub-District, North Sumatra - Lau Kambing and Turangi. These two villages were chosen as the research location because they are the destinations of early Karonese's migration to Salapian Sub-District and mostly inhibited by native Karonese. The data were obtained from 10 informants (5 persons from each of the villages) selected based on the criteria suggested by Milroy and Gordon (2003, p. 15) using interview. The interview conducted in this research was an unstructured, open-ended interview; the interview was audiotaped and transcribed. The data were analyzed using the interactive model proposed by Miles, Huberman and Saldana (2014, p. 31-33). The results of the analysis were then used as the basis of developing the new version of "cengkah-cengkah" game.

\section{DISCUSSION}

Based on the data analysis, it was found that the ecolexicon used in the new version of Karonese traditional game "cengkahcengkah" represented the typical characteristics of Karonese people living in Lau Kambing and Turangi and the hierarchy of merga in the two villages. The new version of cengkah-cengkah keeps most of the rules used in its old version, but modifies several tools used in the game by utilizing the available natural resources in the surrounding ecosystem of Lau Kambing and Turangi. Therefore, no cost is required because whatever needed in the game has been provided by the nature. The new version of cengkah-cengkah is shown in Figure 1.

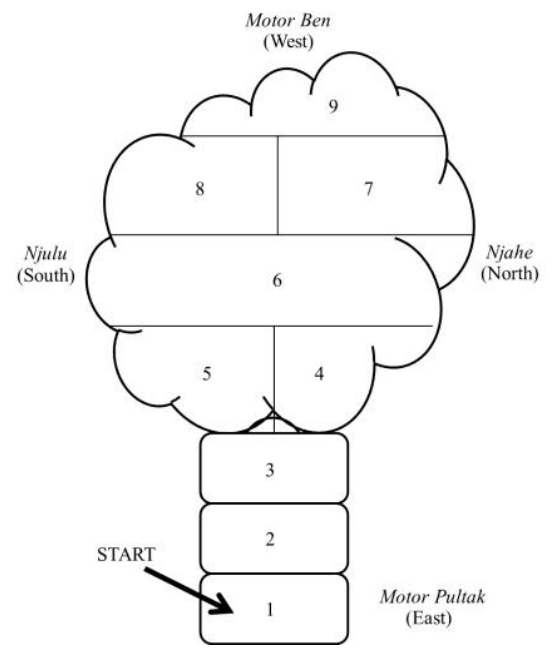

Fig. 1. The new version of "cengkah-cengkah" game

Figure 1 is the picture of the newly developed Karonese traditional game cengkah-cengkah. This 'new version' of cengkahcengkah is developed mainly by involving as muchKaroneseecolexicon as possible in the game for the purpose of maintaining suchecolexicon in the Karonese society in Lau Kambing and Turangi. Most of the ecolexicon introduced in this new version cengkah-cengkahis no longer recognized by the Karonese young generation. The old cengkah-cengkah did not pay attention to the cardinal points of the compass as the arena could be directed into different cardinal points; however, in this new version, the game is guided by such cardinal points. In Karonese language spoken in these two villages, four cardinal points - motor ben (west), 
motor pultak (east), njulu (south), njahe (north) - are recognizeddespite their relatively infrequent use in daily interactions. Based on Tarigan's (2017) findings, the ecolexicon related to cardinal points is no longer used by the age group of 10 to 30 years old Karonese. Those words have been replaced by Indonesian words acquired from their formal education. If these words are not reintroduced and maintained, they will probably die and will not be recognized by the next Karonese generation.

In this new version, the cengkah-cengkah arena should head west (motor ben), the cardinal point of the sunset; in other words, the game starts in the east and ends in the west, corresponding to the day cycle. This represents the daily activities of Karonese people in these villages who leave home in the morning to work and finish their work just before the sunset. Besides, this also contains a local wisdom of Karonese people well-known as hard workers that nothing cannot be achieved because everything is achievable through hard work. By playing this game, Karonese young generation is motivated to draw their aspiration as high as possible which can only be achieved by studying and working hard.

Introducing the Karonese lexicons for cardinal points can also benefit for maintenance of Karonese language. Rarely were these lexicons introduced to children at home; therefore, most of Karonese people within the age of 5 to 25 do not know the Karonese lexicons for cardinal points. Mostly, they acquire these lexicons from school; in other words, their first language for cardinal points was bahasa Indonesia and felt more comfortable to say them in bahasa Indonesia. By introducing cardinal points in cengkah-cengkah game, it is expected that they become more familiar and comfortable to say cardinal points in Karonese language.

Furthermore, this new version of cengkah-cengkah game introduces the Karoneseecolexicon 'bongbong more' reflected through its arena that resembles a bongbong more tree (Ficusracemosa), a species of plant in the family Moraceae, popularly known as a cluster fig tree. It is a native tree throughout the tropics with a few species extending into the semi-warm temperate zone. In Lau Kambing and Turangi, this tree belongs to wild flora and is commonly found in the river banks; however, most of Karonese young generation do not know the Karonese word for this tree because it belongs to wild flora that is rarely used in their daily conversations/interactions. In fact, for the Karonese people living in these two villages, this tree is very beneficial, not for its fruits, but for its ability to prevent the soil on the edge of river from erosion. The strength of this tree inspires the Karonese people in these two villages to make their lives beneficial for others without expecting anything in return. It is just like a bongbong moretree that is ready to always give protection to a river even though the river did not give it anything and may not consider its presence. In addition, this tree also provides a lesson that doing good is a lot more important and a lot greater than gaining popularity, meaning that the best thing to do in our life is always providing benefits to others and never expecting to be known by those taking benefits from us.

This new shape of cengkah-cengkaharena (bongbong more tree-shaped hopscotch) adds the previous 11 shapes of engklek (hopscotch) recorded by Iswinarti (2007) including (i) ship-shaped hopscotch, (ii) mountain-shaped hopscotch, (iii) Red Crossshaped hopscotch, (iv) sliding door-shaped hopscotch, (v) sliding door-shaped hopscotch with modification, (vi) umbrella-shaped hopscotch, (vii) puppets-shaped hopscotch, (viii) chisel-shaped hopscotch, (ix) propeller-shaped hopscotch, (x) television-shaped hopscotch, and (xi) tower-shaped hopscotch.

Another Karoneseecolexicon introduced in this game is buluhbelangke (Gigantochloaapus), a bamboo with long and big segments. In these two villages, this kind of bamboo grows well in the lowlands along river banks. Due to its long segments, it can be used as a good tool to draw lines of the cengkah-cengkah arena on the playground. When used as a drawing tool, the segment was cut into several pieces to form a stick and sharpened at its edge. In addition to drawing better lines, it is not costly and is easily found along the river banks in these two villages. When utilized properly, this kind of bamboo can, actually, become the living source of the local people because it can be used as the raw material to make handicraft and furniture. Setiawati, Mutaqin, Irawan, An'amillah, and Iskandar (2017) found that flexible nature of Gigantochloaapus makes crafters easily form a wide range of household products industry. Therefore, by using this bamboo in playing cengkah-cengkah game, it gains its popularity back and is expected to be utilized by Karonese people in these two villages as their additional living source.

Besides, this new version of cengkah-cengkah uses batu (stone), an ecolexicon related to land matters. The stone is used as ' gacok', the small object leading the game. During the game, the gacok is tossed into numbered spaces (1 to 9) provided in the cengkah-cengkah arena and then the players hop or jump through the spaces to take it back. In the old cengkah-cengkah, the gacok was usually a piece of broken plate. The choice of stone as the gacok in this new version is influenced by economic factor because stone can be easily found anywhere (provided by nature) and this corresponds to the nature of traditional game which is created mainly to stimulate creative faculties of children without any costs (Snel 2009, p. 2). In addition, stone is chosen as the gacok was due to its weight. As this game is played outdoor, and the wind effect is undeniable, the gacok must be so heavy that it cannot be flown by wind. The use of stone also implies that life is heavy requiring people's power and tenacity to survive. The more tenacious someone is, the better life and the higher social status they will get. This also indicates that our life achievement is determined by ourselves because our life cannot get better by itself. In addition, that stone is not easily blown by wind implies that a person with firm stance cannot be easily affected by any obstacles encountered.

Another important rule in playing cengkah-cengkah game is determining who begins the game which is determined through 'sut' (hand game involving fingers). Sut is applied differently in different culture. In the Japanese culture, for example, sut is popularly known as rock-paper-scissors game where rock beats scissors but loses to paper, scissors beat paper but lose to rock, and paper beats rock but loses to scissors. In most of Indonesian cultures, sut is applied by involving three fingers where thumb 
beats point finger but loses to little finger, point finger beats little finger but loses to thumb, and little finger beats thumb but loses to point finger. Meanwhile, in the Karonese culture in Lau Kambing and Turangi, two systems of sut or hand game are applicable: three-finger and five-finger sut systems. The rule of three-finger system - thumb, point finger, little finger - is similar with the other culture's rule. However, Karonese culture has its own interpretation on the rule. Two kinds of ecolexicon associated with animals (fauna) are introduced: gajah (elephant) representing a thumb and perkis (ant) representing a little finger. The other finger, point finger, represents senjata (weapon), which does not belong to ecolexicon. That thumb beats point finger means an elephant can twist a weapon held by a person by using its bulele (trunk), that thumb loses to little finger means an ant can beat an elephant by coming into and tickling its ears, and that point finger beats little finger means a person with his weapon can easily shoot an ant. This Karonese three finger sut system indicates that even small creature has its own advantage.

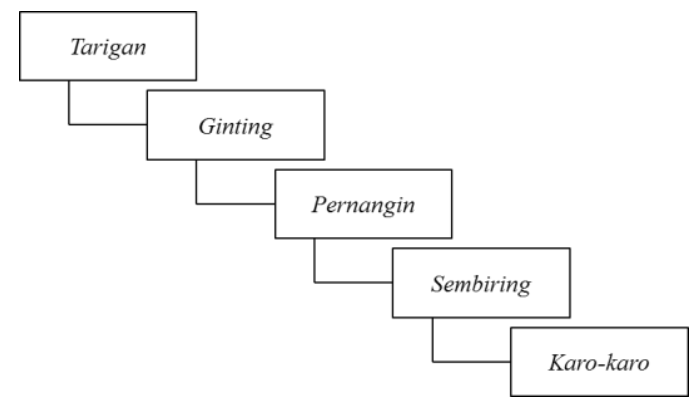

Fig. 2. The hierarchy of mergasilima of Karonese in Lau Kambing and Turangi

Meanwhile, the five-finger sutsystem represents the hierarchy of the five merga or mergasilima (clan hierarchy) in Karonese ethnic group living in Lau Kambing and Turangi (see Figure 2). Even though there are many other Karonesemerga, they are only sub-divisions of these five merga (Sitepu 1995; Sembiring, Sibero, Manik, Munte and Sibero 2002). The Karonese oldest mergain these two villages is Tarigan represented by thumb, the second oldest merga is Ginting represented by point finger, the third oldest merga is Pernangin represented by middle finger, the fourth oldest merga is Sembiring represented by ring finger, and the youngest mergais Karo-karo. The rule says that thumb beats point finger and middle finger but loses to ring finger and little finger, point finger beats ring finger and little finger but loses to thumb and middle finger, middle finger beats point finger and ring finger but loses to little finger and thumb, ring finger beats thumb and ring finger but loses to point finger and middle finger, little finger beats thumb and middle finger but loses to point finger and ring finger. This rule philosophically means that none of the merga is always superior to the other four merga. Although Tarigan is the oldest merga, in some occasions, it must also appreciate the younger merga. By applying this five-finger system, a character of mutual respect (known as aroncharacter) among the Karonese people living in Lau Kambing and Turangi can be built. In Karonese culture, mergaplays such an important role that none of its ethnic group members has nomerga. The importance of merga in Karonese culture is obviously seen during traditional ceremonies or parties where their merga determines their position (Sembiring et al. 2002).

\section{CONCLUSION AND RECOMMENDATION}

Revitalizing the Karonese traditional game "cengkah-cengkah" does not only maintain the Karonese traditional heritage but also maintains the ecolexicon associated with the game. In this new version of cengkah-cengkah, more ecolexiconis inserted in order that such ecolexicon can be maintained and passed to the next Karonese generation. Such ecolexicon contains local wisdom for the people living in Lau Kambing and Turangi, Salapian Sub-district, North Sumatra, particularly in terms of building good character and reminding the hierarchy of merga (mergasilima) in this area.

As the ecolexicon used in the new version of cengkah-cengkah contains local wisdom for the people living in Lau Kambing and Turangi, it is suggested for parents and teachers to encourage children to play this traditional game. In addition to stimulate creative faculties of children, this game also contains local wisdom through the ecolexicon used that needs to be maintained and passed to the next Karonese generation in Lau Kambing and Turangi.

\section{References}

Creswell, J. W. (2012). Educational Research: Planning, Conducting, and Evaluating Quantitative and Qualitative Research. Fourth Edition. Boston, MA: Pearson Education, Inc.

Faber, P., León-Araúz, P. \& Reimerink, A. (2014). Representing environmental knowledge in EcoLexicon. In Languages for Specific Purposes in the Digital Era. Educational Linguistics, 19: 267-301. 
Faber, P., León-Araúz, P. \& Reimerink, A. (2016). EcoLexicon: new features and challenges. In Kernerman, I., Kosem Trojina, I., Krek, S., \& Trap-Jensen, L. (Eds.), GLOBALEX 2016: Lexicographic Resources for Human Language Technology in conjunction with the 10th edition of the Language Resources and Evaluation Conference, Portorož, 73-80.

Hasan, M. (2009). PAUD (Pendidikan Anak Usia Dini). Yogyakarta: Divapress.

Holmes, J. (2013). An Introduction to Sociolinguistics. Fourth Edition. London: Routledge.

Iswinarti. (2007). Permainan Anak Tradisional sebagai Model Peningkatan Kompetensi Sosial Anak Usia Sekolah Dasar. Laporan penelitian. Malang: Lembaga Penelitian UMM.

Jaenudin. (2013). Nama Perkakas Berbahan Bambu dalam Bahasa Sunda di Desa Parapatan, Kecamatan Purwadadi, Kabupaten Subang: Kajian Ekolinguistik. A Thesis. Bandung: Universitas Pendidikan Indonesia.

Lubis, I. S. (2014). Pergeseran Bahasa dalam Permainan Tradisional Mandailing: Kajian Ekolinguistik. Telangkai Bahasa dan Sastra, 8(2): 54-61.

Miles, M. B, A. Huberman, M., and Saldana, J. (2014). Qualitative Data Analysis: A Methods Sourcebook. Third Edition. Thousand Oaks, CA: Sage Publications, Inc.

Milroy, L. and Gordon, M. (2003). Sociolinguistics: Method and Interpretation. Oxford: Blackwell Publishing.

Rochmani, I. (2016). Permainan Tradisional Engklek Berpengaruh terhadap Perkembangan Motorik Anak. A Thesis. Surakarta: Universitas Muhammadiyah Surakarta.

Sapir, E. (2001). Language and Environment. In Fill, A. \& Mühlhäusler, P. (Eds.), The Ecolinguistics Reader. Language, Ecology and Environment. London: Continuum, 13-23.

Sembiring, S. H., Sibero, B. T., Manik, S. D. G., Munte, M. G., and Sibero, G. T. (2002). Adat Perkawinan Masyarakat Batak Karo. Presented at National Seminar on Batak Traditional Wedding Ceremony. Parsadaan Bona Pasogit (PARBOPAS) Daerah Istimewa Yogyakarta, Juni 22, 2002.

Setiawati, T., Mutaqin, A.Z., Irawan, B., An'amillah, A., and Iskandar, J. (2017). Species diversity and utilization of bamboo to support life's the community of Karangwangi Village, Cidaun Sub-District of Cianjur, Indonesia. Biodiversitas, 18(1): 5864.

Sitepu, S. (1995). Sejarah-Pijer Podi adat nggeluh suku Karo Indonesia. Medan: Adiyu.

Snel, C. (2009). The role of traditional children games within the context of intangible heritage. GCAM 4: The Creative Museum: African Museums Using Culture for the Development of Children and Youth. Chief Albert Luthuli Museum, Stanger, South Africa, October 24-29, 2009, 1-5.

Tarigan, B. (2017). Kebertahanan dan Ketergeseran Leksikon Flora Bahasa Karo: Kajian Ekolinguistik. Disertasi. Medan: Universitas Sumatera Utara.

Wardaugh, R. \& Fuller, J. M. (2015). An Introduction to Sociolinguistics. Seventh Edition. New Jersey: Wiley-Blackwell. 